\title{
Understanding The Concept of "Leave to Cleave" inGen.2:24 and Mark 10:7. As A ModelFor Political and Societal Marriage Dynamics
}

\author{
Ikechi Chidi Ekpendu, Ikechi-Ekpendu, Chioma $\mathrm{Msc}^{2}$ \\ Department of Political ScienceBabcock University Ilishan Remo, Ogun State
}

\begin{abstract}
There is a misunderstanding or misinterpretation of the concept of "leave to cleave"in Genesis 2:24 and Mark 10:7. This misunderstanding or misinterpretation has either malfunctioned or destroyed the dynamics of marriage in our society which has affected politics. This paper therefore sought to determine how God's injunction of leave to cleave can change the societal dynamics on marriage. Find out if there is any relationship between leaving to cleave and societal dynamics on marriage. Examine the extent this injunction has been misunderstood, misinterpreted or has influenced societal marriage dynamics and politics.Discover if societal problems associated with marriage could be minimized if couples obey Gods injunction. Quantitative method of inquiry was used in this study and descriptive survey design was engaged.The data collected was analysed by using simple percentage and frequency distribution.The study discovered among others thatMarriages Couples have inability to leave and cleave is dominant Root of marital stress. That the couples who truly leave and cleave to each other affect the society positively.Couples that leave and cleave to each other are able to separate themselves from tension, Influence, and external pressure.The paper concluded and recommended that, going back to God's injunction of leaving to cleave can change the societal dynamics on marriage.
\end{abstract}

\section{INTRODUCTION}

Human society is constantly changing in all areas including relationships more especially in this period of time termed as information and knowledge age and with rapid advancement in information and communication technologies when men and women seem to be wise in their generation. Due to unregenerate nature of many human beings they keep debating, misinterpreting and adjusting God's word to suit their situations at various times. Some do this for political and societal affluence, selfishness and others for satanic tendencies as they have sold their lives to the enemy of their souls.

However no matter the reason man may have for thwarting the Word of God, it is outright disobedience to the Divine Creator. God has given man various institutions, ordinances, injunctions and commandments in order to guide and guard men to live holy and pure lives for God to reveal God's nature of holiness and glory in man's life and for man's own benefits but many people would rather go their own way.

The marriage institution is ordained by God for companionship, intimacy, procreation, sheltering of the family and socializing of the children hence Gods instruction, a man "shall leave his father and his mother and cleave unto his wife: and they shall be one flesh" (Genesis 2: 24). But the reverse is the case, what is observed in the society is outright disobedience to God's Word in the area of marriage which include same sex marriage (homogamy), having more than one wife (polygamy), having more than one husband (polyandry), live in lover or trial marriage and some other ones that negates the principle of oneness, partnership, sexual intimacy and sacredness of marriage all of which are Biblical foundation for marriage. This are all in quest of political affluence and societal influence.

This paper therefore seeks to determine how God's injunction of leaving to cleave can change the societal dynamics on marriage. Find out if there is any relationship between leaving to cleave and societal dynamics on marriage. Examine to what extent God's injunction of leave to cleave influence societal dynamics and discover if societal problems associated with marriage could be minimized if couples leave and cleave.

\section{OPERATIONAL DEFINITION OF TERMS}

According to Oxford Dictionary of Current English, it defines cleave to mean becoming emotionally attached to. It defines leave to mean to let someone do something without helping or interfering; entrust a decision or action to someone, to avoid disturbing or interfering with someone or something; fail to include someone or something. The Online free Dictionary defines leave to mean "to go out or away from, to go without taking or removing, to abandon or forsake, to remove oneself from association with or participation in, to refrain from distributing or interfering, to stop or to cease". This paper however is not working in acceptance of "leave" to 
mean abandonment. The online Macmillan Dictionary agrees with the free online dictionary about the meaning of "leave".

Leave to Cleave: When a man or woman leave parents, relatives and other associates that could negatively impact or affect their marriage.

Societal Dynamics: The ability of a society to react to change.

Different Opinions on Leave to Cleave.

Discussing the concept of leave to cleave in Genesis 2:24, SDA Bible Commentary comments that it is an expression of the deepest physical and spiritual unity of man and woman it goes further to hold up monogamy before the world as the form of marriage ordained by God. It does not in any way recommend a forsaking of filial duty and respect towards father and mother but refer primarily to the fact that a man's wife is to be first and most important in his affections and that his first duty is to her. Tucker explaining Genesis 2:24 illustrates that once a man leaves, he is instructed to "cleave" to his wife. This means to glue, to adhere, to join, to stick.

The Hebrew word used in Genesis is more expressive: to cling, to adhere, to abide fast together, to follow hard after, to be joined together, to keep, to overtake, to pursue, to take. This word makes much emphasis on how a man is to cling and to pursue and join himself to his wife. To strengthen and rekindle marriage relationship, there is a need to evaluate what one is clinging to and pursuing. The New Testament in Matt. 19:45; Mk. 10:7, and 1 Timothy 5:3-4 clearly affirms the Old Testament explanation of leave to cleave to be both physical and spiritual and to supersede all earthly affiliation without parental abandonment.

Laney (2011) in his book The Divorce Myth states that the concept of "leave to cleave" in Gen.2:24 are very essential to marriage success for the coupling effect in two married lovers. Its importance makes for its repetition from creation (Gen.2:24) to the teaching of Jesus on the concept of divorce (Matt 19:5, Mark 10:7) and in Paul's illustration of the mystery of the Church (Eph. 5:31). These scriptures see this concept as prerequisite to proper and effective "one Flesh". Laney further explains that leaving is not always easy, as it is not always easy for children to leave their parents as also parents to leave their children. The leaving does not suggest abandonment of one's parents but the responsibility to honor father and mother (Ex 20:12) is applied.

Tucker (2012) in his book The Foundation Successful marriage agrees with the opinion of Carl Laney. He argues that Gods plan for marriage first involves leaving. God made man and women to leave his parents with a view to establishing his own family. There can be no happy marriage without this first expected step. He further makes comparison stating that without the cuttings of umbilical cord attaching the mother and the baby, the baby cannot grow and mature. Marriage cannot mature and develop unless the man and woman separate from their parents in order to establish a new family. Tucker opines that marriages fail because they stumble on the action of leaving which interestingly is addressed primarily to men. Which implies men leaving parents and find employment, clothing, shelter and independence for him? He needs to leave school chums, single lifestyle and other hobbies and distractions and cleave to his wife. Suggesting that wife's should be superior to other earthly relationships of the man.

Donald and Robbie Joy (1982) in their book Two Becomes One see the concept of leave and cleave to be an act or process of bonding which is a clear explanation of what it means to become one flesh. Again Donald Joy(1995) In another book Risk-Proofing Your Marriage supports the concept of leave to cleave to be as a caution to protect the intimacy bond as the scripture puts it, what God has joined together, let no man put asunder. He emphasizes this concept as prerequisite to bonding. In the same authors another book, Becoming a Man, he further supports the concept as the best way of having to achieve the ultimate bond. The authors argues that both couple must separate themselves from all other and every other earthly attachment and cleave to each other then can effective bonding be seen. Without which, marriage cannot be in order for it to be enjoyed but it will be endured.

Ruth and Philemon (2014) opines that marriage in adherent to biblical instruction of leave to cleave is one of the initial and first gifts of God to man which Adam brought with him beyond the gates of paradise after the fall. Both authors argue that the biblical injuction in the Old and New Testaments of the bible is the prerequisite to becoming one flesh and staying together as one with northing between them both. Accepting that this oneness is compare to the relationship that Jesus has the church, both authors strongly agree that the concept of leave to cleave is a clear support of monogamy and heterosexuality.

Marital intimacy is the act of love that never involves anyone else. It is a unique joining of two people into one entity. Meaning that quitting or divorce is not an option when thing are not going right. It includes talking things over, praying them through, being patient as one trust God to work in hearts and minds involved. This involves being willing to admit when each party is wrong and asking for forgiveness and seeking Gods council regularly in His word. Furthermore, the refusal of spouses to truly leave their parents, conflict and stress will be the result. This is also in agreement with other scholars positing that leaving parents means recognition that a new marriage is the creation of a new family and this new family must be a higher priority than the 
previous. Leave to cleave is key to building a marriage that will endure hard times and be the beautiful relationship that God intends it to be.

Survey Report

The study is descriptive survey design. It used survey method by using questionnaire technique to elucidate information on how God's injunction of leaving to cleave can change societal dynamics on marriage. The population for this study were the Postgraduate students of Babcock University (Summer School 2014). Twenty out of about thirty eight students who included both male and female married and unmarried students were used. The research instrument that was used was a questionnaire entitled. It was structured into two parts: the first part elucidated relevant demographic data from the students while the second part was a Likert Scale format containing questions on God's injunction of leave to cleave and changing societal dynamics on marriage. The questionnaire was personally administered on the students by the researchers. The data collected was analysed by using simple percentage and frequency distribution. A number of tables are applied in analysing the responses from the question, frequency and percentage calculated to see how the respondents respond to the questions and analysis of the responses collected through the administered with the aim of finding answers to the research questions.

Table 1.1Return Rate of Questionnaire Distributed

\begin{tabular}{|l|l|l|}
\hline & Frequency & Percentage \% \\
\hline Questionnaire Returned & 20 & 70 \\
\hline Questionnaire Not Returned & 10 & 30 \\
\hline Total & 30 & 100 \\
\hline
\end{tabular}

From the above table, it shows that $70 \%$ of the questionnaires were returned and $30 \%$ not returned, this indicates that most of the questionnaires were returned.

Table 1.2 Bio data Of Respondent

\begin{tabular}{|l|l|l|l|}
\hline Characteristics & Information & Frequency & Percentage \\
\hline Gender & Male & 9 & 45 \\
& Female & 11 & 55 \\
\hline Marital Status & Single & 9 & 45 \\
& Married & 11 & 55 \\
& Divorce & Nil & \\
\hline Marriage years & Below 5 years & 2 & 15 \\
& 5-10 Years & 4 & 40 \\
& 10-15 Years & 3 & 20 \\
& Above 15 Years & 2 & 15 \\
\hline
\end{tabular}

The respondent comprise of both single and married, with more of them being female. Most of the respondent were married and for over five years. Q1 Do you understand the phrase Leave to Cleave?

Table 1.3

\begin{tabular}{|l|l|l|}
\hline RESPONSES & FREQUENCY & PERCENTAGE \\
\hline STRONGLY AGREE & 10 & 50 \\
\hline AGREE & 10 & 50 \\
\hline UNDECIDED & & \\
\hline DISAGREE & & \\
\hline STRONGLY DISAGREE & & \\
\hline TOTAL & 20 & 100 \\
\hline
\end{tabular}

From the table above, $50 \%$ of the respondent strongly agree and $50 \%$ of them agree to the fact that they understand what it means to Leave and cleave. Q2. When you leave to cleave, you leave all form of tangible and intangible relationship and cleave to your Spouse.

Table 1.4

\begin{tabular}{|l|l|l|}
\hline RESPONSES & FREQUENCY & PERCENTAGE \\
\hline STRONGLY AGREE & 13 & 65 \\
\hline AGREE & 5 & 25 \\
\hline UNDECIEDED & 1 & 5 \\
\hline
\end{tabular}


Understanding The Concept of "Leave to Cleave" inGen.2:24 and Mark 10:7. As A Model

\begin{tabular}{|l|l|l|}
\hline DISAGREE & 1 & 5 \\
\hline STRONLY DISAGREE & & \\
\hline TOTAL & 20 & 100 \\
\hline
\end{tabular}

$65 \%$ of the respondent strongly agree, $25 \%$ agree while $10 \%$ are undecided and disagree with the question. Q3. Couples inability to leave and cleave is dominant Root of marital stress. Table 1.5

\begin{tabular}{|l|l|l|}
\hline RESPONSES & FREQUENCY & PERCENTAGE \\
\hline STRONGLY AGREE & 6 & 35 \\
\hline AGREE & 9 & 45 \\
\hline UNDECIEDED & 1 & 5 \\
\hline DISAGREE & 1 & 5 \\
\hline STRONGLY DISAGREE & 2 & 10 \\
\hline TOTAL & 20 & \\
\hline
\end{tabular}

$80 \%$ of the respondent agree to this question while $20 \%$ do not agree. Q4. Marriage is forced to bear burden when couple fails to leave and cleave.

Table 1.6

\begin{tabular}{|l|l|l|}
\hline RESPONSES & FREQUENCY & PERCENTAGE \\
\hline STRONGLY AGREE & 11 & 55 \\
\hline AGREE & 8 & 40 \\
\hline UNDECIEDED & & \\
\hline DISAGREE & & \\
\hline STRONGLY DISAGREE & 1 & 5 \\
\hline TOTAL & 20 & 100 \\
\hline
\end{tabular}

From the table above, $95 \%$ of the respondent strongly agree and agree to this question and 5\% strongly disagree. Q5. Leave to cleave should occur only in the beginning of a marriage.

Table 1.7

\begin{tabular}{|l|l|l|}
\hline RESPONSES & FREQUENCY & PERCENTAGE \\
\hline STRONGLY AGREE & 3 & 15 \\
\hline AGREE & & \\
\hline UNDECIEDED & 1 & 5 \\
\hline DISAGREE & 8 & 40 \\
\hline STRONGLY DISAGREE & 8 & 40 \\
\hline TOTAL & 20 & 100 \\
\hline
\end{tabular}

To this question $80 \%$ of the respondent disagree and strongly disagree,5\% are undecided and $15 \%$ strongly agree. Q6. Leave to cleave should be a way of life through Out the marriage.

Table 1.8

\begin{tabular}{|l|l|l|}
\hline RESPONSES & FREQUENCY & PERCENTAGE \\
\hline STRONGLY AGREE & 11 & 55 \\
\hline AGREE & 9 & 45 \\
\hline UNDECIEDED & & \\
\hline DISAGREE & & \\
\hline STRONGLY DISAGREE & & \\
\hline TOTAL & 20 & 100 \\
\hline
\end{tabular}

The whole respondent agree and strongly agree with this question. Q7. Couples these days truly leave and cleave to their spouse.

Table 1.9

\begin{tabular}{|l|l|l|}
\hline RESPONSES & FREQUENCY & PERCENTAGE \\
\hline STRONGLY AGREE & 1 & 5 \\
\hline AGREE & 2 & 10 \\
\hline
\end{tabular}


Understanding The Concept of "Leave to Cleave" inGen.2:24 and Mark 10:7. As A Model

\begin{tabular}{|l|l|l|}
\hline UNDECIEDED & 5 & 25 \\
\hline DISAGREE & 11 & 55 \\
\hline STRONGLY DISAGREE & 1 & 5 \\
\hline TOTAL & 20 & 100 \\
\hline
\end{tabular}

The above table shows that $60 \%$ of the respondent disagree with this question, $15 \%$ agree while $25 \%$ are undecided. Q8. Marriages that the couples truly leave and cleave to each other affect the society positively.

Table 1.10

\begin{tabular}{|l|l|l|}
\hline RESPONSES & FREQUENCY & PERCENTAGE \\
\hline STRONGLY AGREE & 11 & 55 \\
\hline AGREE & 7 & 35 \\
\hline UNDECIEDED & 1 & 5 \\
\hline DISAGREE & & \\
\hline STRONGLY DISAGREE & 1 & 5 \\
\hline TOTAL & 20 & 100 \\
\hline
\end{tabular}

The table above shows that $90 \%$ of the respondent agree with this question.

Q9. Couples that leave and cleave to each other Are able to separate themselves from tension, Influence, and external pressure.

Table 1.11

\begin{tabular}{|l|l|l|}
\hline RESPONSES & FREQUENCY & PERCENTAGE \\
\hline STRONGLY AGREE & 10 & 50 \\
\hline AGREE & 8 & 40 \\
\hline UNDECIED & 1 & 5 \\
\hline DISAGREE & & \\
\hline STRONGLY DISAGREE & 1 & 5 \\
\hline TOTAL & 20 & 100 \\
\hline
\end{tabular}

The table above shows that $90 \%$ of the population agree and strongly agree to this question.

Q10. leaving parents and cleaving to one's spouse in Marriage will help prevent sexually related sins in our society.

Table 1.12

\begin{tabular}{|l|l|l|}
\hline RESPONSES & FREQUENCY & PERCENTAGE \\
\hline STRONGLY AGREED & 8 & 40 \\
\hline AGREED & 7 & 35 \\
\hline UNDECIEDED & 2 & 20 \\
\hline DISAGREE & 1 & 5 \\
\hline STRONGLY DISAGREE & 2 & 20 \\
\hline TOTAL & 20 & 100 \\
\hline
\end{tabular}

The above table show that $40 \%$ strongly agree, $35 \%$ agree,20\% are undecided,25\% disagree and strongly disagree.

Q11. If the society could go back to God's injunction that a man should leave his parent and cleave to his wife ,societal problems associated with marriage will be minimized.

Table 1.13

\begin{tabular}{|l|l|l|}
\hline RESPONSES & FREQUENCY & PERCENTAGE \\
\hline STRONGLY AGREE & 13 & 65 \\
\hline AGREE & 5 & 25 \\
\hline UNDECIEDED & 1 & 5 \\
\hline DISAGREE & & \\
\hline STRONGLY DISAGREE & 1 & 5 \\
\hline TOTAL & 20 & 100 \\
\hline
\end{tabular}

The table above shows that $90 \%$ of the respondents strongly agree and agree to this question. 


\section{SUMMARY, CONCLUSION AND RECOMENDATION}

God's injunction leave to cleave is clearly understood by respondents of this study and they also know that when you leave to cleave, it is not only in the beginning of the marriage but a way of life throughout the marriage and that you leave all form of tangible and intangible relationship and cleave to your spouse, and become one flesh that live together forever. It is agreed that Couples inability to leave and cleave is the dominant root of marital stress, which forces Marriages to bear burden, which in turn have negative impact on the society The study found out that Couples these days do not truly leave and cleave to their spouse, even though Marriages that the couples truly leave and cleave to each other affect the society positively, because they are able to separate themselves from tension, Influence, and external pressure and will help prevent sexually related sins in Our society, and if the society could go back to God's declaration, that a man should leave his parent and cleave to his wife ,societal problems associated with marriage will be minimized. It is evident from response that Gods injunction of leave to cleave has effect on our societal dynamics with respect to marriage.

\section{CONCLUSION}

In conclusion, going back to God's injunction of leaving to cleave can change the societal dynamics on marriage. There is a strong relationship between God's, injunction of leave to cleave and societal dynamics on marriage, this is so because, when couples truly leave and cleave to one another , they tend to impact the society positively, and most problems associated with marriage such as divorce, sexual abuse, incest and so on will be avoided. "Leave to Cleave "the injunction given by God to man in Genesis 2:24, has been given little attention or concern in the life of our present day married men. Who have rather become influenced and carried away by societal dynamics against the word of God. They no longer see marriage as an institution by God at Eden; it is now looked at as a contract and a relationship that can dwindle and die off with little or no challenge, the survival of marriage relationship is now at their convenience and comfort alone. This paper has been able to outline what it means to leave according to Gods word. Seeing that remaining under the dictates of parents, sisters, brothers or loved ones can cause damage to the relationship of a husband and wife. And could lead to neglect, violence, separation and even divorce. The Lord who is all knowing now advice that the man, who is usually attached so much to dear ones, should leave every distraction and cleave unto his wife. This bible text reminds us that marriage supersedes all previous associations. The question is asked what are those things we ought to leave when we are married. Those lifestyle that cause distractions and interference with our spouses has to be avoided. And though this instruction is for men, ladies should encourage their spouse in the cleaving process. Societal dynamics, are x-rayed in this work, but there is that call to go back to the word of God, the Bible on "LEAVING TO CLEAVE".

\section{RECOMMENDATION}

It is recommended that humanity should follow God's injunction that a man should leave his parent and cleave to his wife and they become one flesh, for this makes the marriage, family and society a better place for all looking at our society now, and the societal infiltrations into the marriage institution, some recommendations are made in this work.

1. There is a great call by Genesis 2:24, mark 10:7, to go back to the Bible, that every husband or husband to be ought to hold on to. The word of God says we must leave our parents in order to cleave to our spouses.

2. More attention should be given to our spouses than any other person. The welfare and happiness of our spouses supersedes that of any other person.Every other person including the parents are secondary.

3 The introduction of house-helps or maids should be cut off, and where there is difficulty in doing that it should be reduced to the barest minimum. This enables the couple for proper bonding or cleaving as proposed by the word of God, since this could also cause distractions and abandonment of responsibilities, which severes marriage.

4. Husbands should not live with their spouses in the house of the parents. He should have his own apartment to be independent of dictatorship from his parents.

5. It is recommended that great emphasis be placed in the teaching of this concept "Leave to Cleave". This should be taught in schools, in Churches and the society, as it is the bedrock of a successful home, because the devil has brought up reasons why this concept should be undermined.

\section{REFERENCE}

[1] Amanze, Ruth \& Philemon(2014)Become A Better Family, Lagos: Jamiro Press Link.

[2] Tucker,Billy W. (2012)What God Hath Joined Together, a book posted on www.trinityhighrolls.org extracted on July, 2014.

[3] Francis D Nichol, Raymond F. Cotterell, Don F. Neufeld (Eds).(1956)Seventh Day Adventist Bible

[4] Commentary, Vol.5. Washington, D.C: Review and Herald Publishing Association.

[5] Francis D Nichol, Raymond F. Cotterell, Don F. Neufeld (Eds).(1956)Seventh Day Adventist Bible 
[6] Commentary, Vol.1. Washington, D.C: Review and Herald Publishing Association.

[7] Donald M. Joy (1955)Risk-Proofing Your Family. California: William Carey Library.

[8] Donald M. Joy (2001) Becoming a Man, India: Evangel Publishing House.

[9] Donald and Robbie Joy(2002)Two Become One. India: Evangel Publishing House.

[10] Oxford Dictionary of Current English, $4^{\text {th }}$ Edition. New York: Oxford University Press, 2006.

[11] The Holy Bible

[12] www.thefreedictionary.com 